\begin{tabular}{|c|c|c|}
\hline \multirow{2}{*}{\multicolumn{2}{|c|}{\begin{tabular}{l|l} 
DE & DE GRUYTER \\
OPEN
\end{tabular}}} & ECONOMIC THEMES (2017) 55(4): 451-463 \\
\hline & & DOI 10.1515/ethemes-2017-0025 \\
\hline
\end{tabular}

\title{
TESTING INSTABILITY IN GROWTH PATTERNS IN THE COURSE OF TRANSITION: EVIDENCE FOR BALKAN COUNTRIES *
}

\author{
Nataša Trajkova-Najdovska \\ University St. Kliment Ohridski - Bitola, Faculty of Economics - Prilep, FYRM \\ natashatrajkova@yahoo.com
}

\section{Snežana Radukić}

University of Niš, Faculty of Economics, Republic of Serbia

$\square$ snezana.radukic@eknfak.ni.ac.rs

UDC

$330.35(497)$

Review

paper

\begin{abstract}
Stylised facts of GDP growth patterns of developing (or transition) countries reveal huge difference to the GDP pattern observed in developed countries. Namely, they are characterised by a specific characteristic - instability, much higher and different from the ones observed in developed countries. This paper brings forward the assessment of the instability of growth, which is observed and tested in the case of several Balkan economies. In the course of transition, they experienced sudden turns from positive to negative average growth rates (or vice versa) caused by many structural, economic, political and social changes. Hence, the main purpose of the paper is to review the very recent literature on instability in growth and to empirically analyse it in the case of Balkan group of transition economies, performed by use of the simple linear regression analysis on the GDP growth data series. Main goal is to determine whether GDP growth patterns in the course of transition were characterised by instability and breaks. The results suggest that the growth process in Balkan economies cannot be described simply by a single rising trend, since the simple linear regression analysis shows very poor statistical fit. In general, the assessment guides towards an in-depth study of the instability of growth in the course of transition with a novel growth concept that will allow for shifts or breaks in trend, accompanied by a non-linear modelling approach that will allow the parameters to adjust to reflect structural changes in the course of transition.
\end{abstract}

\footnotetext{
* This research is conducted by the financial support from the CERGE -EI Teaching Fellowship Programme. The views and the opinions are those of the authors and do not necessary reflect the official policy or position of The Center for Economic Research and Graduate Education Economics Institute (CERGE-EI) in Prague. Also, this research is part of the project No. 44007 supported by Ministry of Education, Science and Technological Development of the Republic of Serbia.
} 
Received:

08.12.2017.

Accepted:

12.01.2018.
Keywords: instability, economic growth, transition economies, Balkan countries, GDP data series, linear regression analysis.

JEL classification: O40, P20

\section{Introduction}

Pritchett (2000) claimed that nothing that is true about GDP for the developed countries is true for developing (or transition) countries. Namely, there are many ways in which the behaviour of the GDP of poorer countries looks very different to that of rich countries Durlauf et al. (2004). For example, while growth in the United States “...displays as a modestly sloping, only slightly bumpy hill...”, per capita GDP in most developing countries does not follow a single time trend according to Pritchett (2000, p. 1).

In fact, growth in developing countries is characterised by a peculiar characteristic - instability, much higher and different from the ones observed in developed countries (Ben-David \& Papell, 1997, Pritchett, 2000, Durlauf et al., 2004). In general, instability of growth can be explained as sudden turns from positive to negative average growth rates (or vice versa) after a certain point in time, i.e. turnarounds or growth meltdowns (Ben-David \& Papell, 1997, Pritchett, 2000). This peculiarity of growth, especially evident and interesting in the case of developing and transition countries, have drawn researchers' interest towards deeper analysis of the dynamic of output in the wake of collapses and sharp rises, because it differs greatly from its dynamics at other "rather steady" times.

As a result, the observed stylised facts about variations in growth patterns among developed and developing countries have occasioned new approaches to growth theory. Before, mostly, studies on developed countries discussed steadystate growth and considered whether all countries in the convergence club will reach the same happy level in the end (Pritchett, 2000). Following this example, studies of developing countries adopted similar approaches, thereby underestimating the importance - and ignoring the implications - of the instability of the growth rates, which are more relevant not only for the case of developing countries, but also for the case of those in transition. When taken into account, instability of growth change the whole conception of the linear growth steady-state path, as established in neoclassical growth theory, and put forward the idea of growth interrupted by break points and turns that can be described as transitions between different growth regimes (Pritchett, 2000). Hence, in this paper the goal is to assess critically the newest breakthroughs in growth literature on shifts in growth regimes (instability) in order to then apply it in the context of group of transition countries (Easterly et al., 1993; Ben-David \& Papell, 1997; Pritchett, 2000; Hausmann et al., 2004; Aquiar \& Gopinath, 2004; Easterly, 2009; Jerzmanowski, 2006; Durlauf et al., 2008). 
The paper is structured as follows. Firstly, the stylised facts of the economic growth patterns for Balkan countries are presented, motivating the debate on instability. Subsequently, the review of the recent theory and empirical findings related to instability is presented, setting the rationale for the empirical analysis of the GDP growth rates time series. The final part sets out the conclusions.

\section{Stylised facts of the economic growth patterns in Balkan countries}

The group of countries included within this research consist of the so-called group of lagging transition countries, South Eastern European Countries (SEECs) or Balkan Transition Countries including: Croatia, Macedonia, Albania, Bosnia and Herzegovina, Serbia, Montenegro, Romania and Bulgaria. Montenegro proclaimed independence comparably later than the other countries, in 2006, which significantly shortens the data series. Bosnia and Herzegovina also has short data series. Hence, these two countries are not included in the regression analysis. All these countries belonging to the Balkan Peninsula, share several common characteristics: common geographical region, common state (some of the countries), common socialistic history, accompanied by the absence of market mechanism and its supportive institutions, broadly distorted structure of factors, production and output, obsolete physical capital, outdated organisational structures, business and management skills, and questionable professional work methods and ethics (Svejnar, 2002, Kornai, 2006, Balcerowicz, 2001). On these grounds, they were challenged to build a modern market economy together with parliamentary democracy, while opening their borders for cooperation with the rest of the world (Blanchard, 1997).

The beginning of transition was marked by a sharp decrease in economic activity in all these economies (Berg et al., 1999). Separate graphs in Figure 1 presents growth rates in the Balkan transition countries, measured by the annual percent change of GDP per capita. On the graphs, the $\mathrm{x}$ - axis gives the time line, while $\mathrm{y}$ - axis represents the growth rates measured in percentages. Big shifts in data series from positive to negative growth rates (and vice versa) are marked in circles.

A caveat about the time span, quality and comparability of data should also be introduced at this point. Dabrowski et al. (2000) document several data related problems: short annual data series and their understatement during transition because of tax evasion, the large informal sector and weak statistical institutions. In addition, in the case of some countries, for example for Bosnia and Herzegovina, Serbia and Montenegro, data are incomplete or suspicious for periods of war and conflicts. In general, transition researchers agree upon the fact that no "single true real GDP series” exists for transition countries, emphasising the need for their careful interpretation (De Melo et al., 1996). In addition, since the main idea is to 
observe the sharp switches in the data series, the annual frequency of the data is used in this research. The higher frequency has a property to mask the changes of interest.

Figure 1. GDP growth rates in Balkan Transition Countries
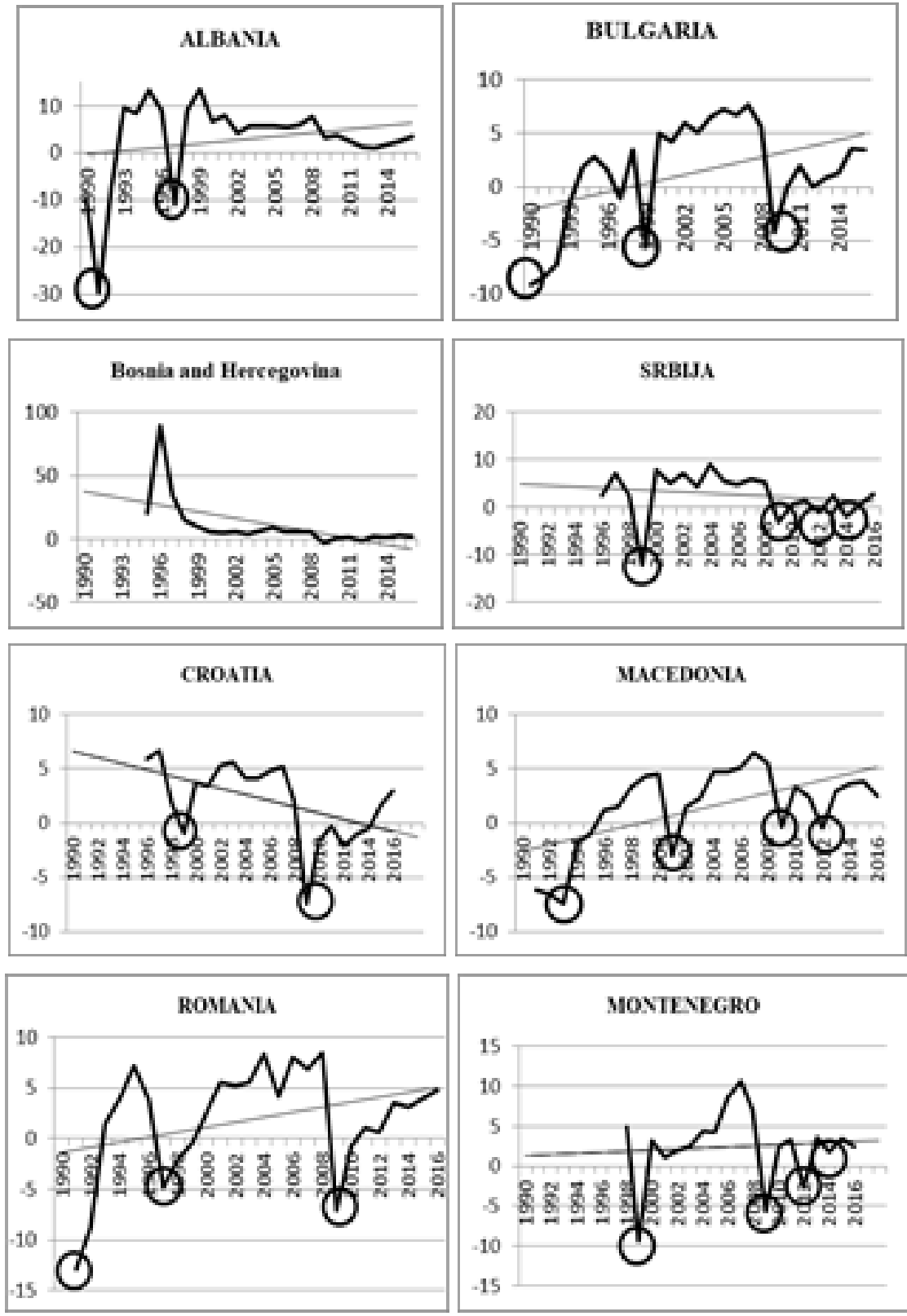

Source: World Development Indicators, World Bank, 2017. 
Graphs are not precisely comparable, as the y - axes are not marked in same scale span. However, the idea is not to compare the economic growth patterns amongst countries, but rather to observe the big switches from positive to negative (or vice versa) economic growth rates. All graphs include the linear trend line, given in black colour. As can be noticed, Bosnia and Herzegovina is a specific case, recording growth rates of 88, 34 percent for 1996, 97, which is rather suspicion achievement for the years of war. In addition, the data series for some of the countries start in later transition, such as Serbia, Croatia and Montenegro.

The figure reveals several characteristics:

- Firstly, the severity of starting recession differed across countries, with Albania recording the sharp decrease in economic activity (-30) and Macedonia, Romania and Bulgaria undergoing less severe decline (to levels of $-8,-13,-9$ percent, respectively).

- The second point is related to sharp reversals in the growth rates in later transition. Most of the countries record negative growth rates in a middle transition (marked by circles in the graphs above). For some of the economies, the reversals repeated three or four times, contracting the economic activity severely.

- Lastly, the Financial Crisis hit the economies with different severity, with Croatia, Romania, Bulgaria experiencing the biggest falls. Evidently, the Crisis hit hardest the most developed ex-transition countries that became members of the European Union in 2004, leaving the Transition World, while it exerted less influence on the lagging transition economies, such as Macedonia, Serbia, Albania (European Bank for Reconstruction and Development, 2009).

- The stylised facts of the figure above alternate the whole conception of the linear growth steady-state path, as established in neoclassical growth theory. They put forward the idea of growth interrupted by break points and turns that can be described as transitions between different growth regimes as explained by Pritchett (2000). Hence, the theoretical and empirical analysis of the breaking points in growth patterns has to determine whether their actuality was significant element, and whether it influenced the further growth path.

\section{Theoretical background and empirical findings}

The debate over the instability of growth started in the early nineties, possibly motivated by the seminal work of Perron (1989) who challenged the conventional understanding of the data generating processes (DGP) of macroeconomic data series. Namely, the conventional perception of most macroeconomic data series was based on the findings of Nelson and Plosser (1982), who argued that almost all macroeconomic time series have a unit root. They suggested that random shocks have permanent effects on the long-run level of macroeconomic variables; that is, 
that the fluctuations are not transitory. As a result, these non-stationary series follow a random walk and have no tendency to return to a long-run deterministic path and their variance is time dependent. As mentioned, later, Nelson and Plosser's findings were challenged by Perron (1989), who claimed that most macroeconomic series are not necessarily characterised by a unit root but, rather, by:

- Structural breaks due to large and infrequent shocks, which characterise a country's long-run development; and,

- Deterministic trends between the breaks, which are characterised by small and frequent shocks after which the economy returns to the trend.

Hence, Perron's (1989) proposal was to allow for huge structural breaks when analysing macroeconomic data series, suggesting that:

"Most macroeconomic time series are not characterised by the presence of a unit root. Fluctuations are indeed stationary around a deterministic trend function. The only shocks which have had persistent effects are the 1929 crash and the 1973 oil price shock" (Perron, 1989, p. 1361).

Perron (1989) asserted that in the presence of a structural break, caused by a big shock, the standard unit root test such as Dickey-Fuller test is biased towards non-rejection of the null hypothesis of a unit root. From the growth literature perspective, Perron's (1989) study, although mainly empirically based, allowed for development of new perception of growth, different from the one established in the neoclassical theory. It showed that distinction of the types of shocks that hit a particular country can be very important for understanding the whole process of growth. Namely, according to Perron (1989) in some cases when the shocks hitting an economy are sufficiently big they can move a country from one deterministic trend to another. Later this idea enabled definition of the instability of growth as a peculiar characteristic of the growth process. On the other hand, small shocks that cause only fluctuations around a deterministic trend generate the volatility of growth. These ideas motivated the emergence of the conception of growth as transitions between various trend lines or regimes, characterised by specific volatility within each trend, instead of simply a linear process characterised by business cycle fluctuations (Abramovitz \& David, 1973). Additionally, it spurred further investigation of shocks that hit one economy and their impact on growth and real GDP data series.

Easterly et al. (1993) discussed the sudden shocks and their underlying relation with the instability of growth, which they believed are ignored in growth theoretical and empirical literature. They found that the country specific shocks are hugely important for the medium-term growth of each country and, hence, they proposed growth studies to be focused on the analysis of growth within individual countries. Namely, Easterly et al. (1993) showed that correlation of growth across 
decades (1960-70 and 1970-80) within countries is very low - averaging from 0.1 to 0.3 in a worldwide sample of 115 countries. The possible explanation for the low persistence of growth rates is the role of shocks in growth shifts, such as the terms of trade, external transfers, the change of number of war related causalities and the presence of a debt crisis. More precisely, they argued that shocks are important over decade-long periods, since they influence policy variables and thus estimates of the impact of policies. The main implication of their study was that most of the variation in growth is within individual countries, rather than across countries. In the later analyses, Easterly et al. (2000) focused rather on the developing countries, claiming that the economic crises gained in frequency and severity in developing countries, especially in the past quarter century. They claimed that the causes and nature of these crises have differed vastly among developed and developing countries, especially hitting the less developed economies.

In similar manner, emphasising the impact of the shocks in the economy, BenDavid and Papell (1997) identify a statistically significant single structural break in the growth series for 54 countries out of set of 74 countries from 1955 to 1990 . Beginning with the scan of output (in levels), defined as the logarithm of real GDP per capita, they used Perron's (1989) testing procedure to identify structural breaks in the data series. The algorithm actually identified structural breaks on purely statistical grounds and the unit root null was rejected for 20 countries in their sample. Additionally, they applied the test in first differences for the series in which a unit root could not be rejected. Finally, they found 54 countries in total in which a structural break was statistically significant either in levels or rates analysis. In general, the reasons behind the big shocks were different: for the developed countries, the breaks were associated with the collapse of the BrettonWoods system and the first oil embargo; while the meltdowns, i.e. the growth slowdowns in developing countries, commenced with the second oil shock and the start of debt crisis.

Motivated by the similar idea, i.e. the variation of growth among countries, later on, Pritchett (2000) developed further the idea of changes in growth regimes, which are experienced mainly by developing economies due to big shocks recorded in these countries, as oppose to a consistent convergence process, characteristic for developed countries. In order to examine the differentiation among growth in developed and developing countries, firstly he tested how much of the country's time-series behaviour is just a trend, interpreting the $\mathrm{R}^{2}$ of the simple regression line as an indicator of fit, i.e. fitting a single time trend through $y$ for the whole period in the case of 111 developed and developing countries. The list of countries he uses is long, grouping the countries of interest in two groups: OECD developed countries and developing countries, in accordance with the custom classification. The estimated regression is:

$$
\ln \left(y_{t}\right)=a+b_{t}+e_{t},
$$


where $y$ is real GDP, $b$ is the trend coefficient, or calculated Least squares growth rate, $e_{t}$ is the error term and $t$ is the time subscript.

The time horizon is 1960-1992, and the frequency of data is quarterly in Pritchett's analysis (2000). His findings are appealing. In the developed-country sample the median $\mathrm{R}^{2}$ is 0.95 , with standard deviation of only 0.03 ; while for the developing-country sample the median $\mathrm{R}^{2}$ is only 0.67 , with a standard deviation of 0.32 . Hence, for nearly all industrial countries the total variance of the time series is almost completely summarised in a single number - the average growth rate, while in contrast in developing countries the $\mathrm{R}^{2}$ values are distributed over the entire $(0,1)$ range. After summarising the results into two groups, developed and developing countries, he concluded that OECD countries have business cycle fluctuations, but these are not the dominant features of the evolution of their GDP. In contrast, for the developing countries, growth is not just the trend, but it is characterised by sudden changes, which cause shifts in growth. In the long run, even small shifts in growth turn into huge shifts in living standards and even more sustained large differences into seismic shifts.

In this line of research, Pritchett (2000) suggested that an empirical method that will be able to depict individual countries' growth patterns through their breaks and changes will be useful for deeper understanding of growth process, especially in developing (or transition) countries.. Conversely, “...the use of panel data to investigate the effects of long-term growth in developing countries - especially with fixed effects estimates - is potentially more problematic than helpful" (Pritchett, 2000, p. 1).

\section{Assessment of instability of growth in transition countries}

\subsection{Modelling procedure}

Following Pritchett's idea, this section aims to test how much of the country's time-series behaviour is just a trend, by the interpretation of the $\mathrm{R}^{2}$ of the simple regression line as an indicator of fit, i.e. fitting a single time trend through $y$ for the whole period of transition in the case of Balkan economies.

The definition of instability is borrowed from Pritchett (2000) where instability is defined as shifts in growth trend. The annual data on GDP growth rates or GDP (in constant 2000 U.S. dollars) used in the analyses are taken from the World Bank (2016) data series; and finally, the equation calculated is:

$$
\dot{y}_{t}=\hat{\alpha}_{0}+\hat{\beta} T+\hat{e}_{t}
$$


The main goal is to test how much of the series behaviour of the growth rates in transition countries is just a trend. In Equation 2, $y$ is the dependent variable (GDP growth rate), $\hat{\alpha}_{0}$ is the constant, $\hat{\beta}$ is the coefficient to be estimated on the deterministic time trend $t$ and $e_{t}$ is the error term. In economic terms, the variables from the equation take different meanings: a significant constant in this model indicates the average growth rate at the beginning of transition, while a significant positive trend indicates a continuous increase in the growth rate. In this case, the data used for the dependent variable is the GDP growth rate from the World Bank (2016).

\subsection{The results}

The following Table 1 summarises the results of each individual country. In the columns various estimated coefficient are presented: column (1) gives the constant term and its p-value in parentheses, column (2) presents the trend term and its pvalue. While a significant constant coefficient presents the growth rate at the beginning of transition, a significant trend coefficient should represent a constant change in the growth rate. Columns (3) and (4) give the mean value of the growth rate in each country and its standard error, while column (5) gives the R-squared, i.e. the measure of goodness of fit of the regression.

Table 1. Fitting a single trend through GDP growth rates (results from Equation 2)

\begin{tabular}{|l|l|l|l|l|l||}
\hline Country & $\begin{array}{c}\text { Constant term } \\
\left.\text { (in percent, } \alpha_{0}\right) \\
(\mathrm{p} \text {-value) } \\
(1)\end{array}$ & $\begin{array}{c}\text { Coefficient on } \\
\text { trend } t \text { (in percent, } \\
\beta \text { ) }(\mathrm{p} \text {-value) } \\
(2)\end{array}$ & $\begin{array}{c}\text { Mean (in } \\
\text { percent) } \\
\left(\begin{array}{c}\left.y_{t}\right) \\
(3)\end{array}\right.\end{array}$ & $\begin{array}{c}\mathrm{SE}(\mathrm{Y}) \\
\text { (in } \\
\text { percent) } \\
(4)\end{array}$ & $\begin{array}{c}\mathrm{R}^{2} \\
(5)\end{array}$ \\
\hline \hline Albania & $-8.67(0.2347)$ & $0.59(0.0998)^{* * *}$ & 3.03 & 9.84 & 0.14 \\
\hline Bulgaria & $-11.98(0.0041)^{*}$ & $0.65(0.0019)^{*}$ & 0.77 & 5.94 & 0.42 \\
\hline Croatia & $-5.34(0.1529)$ & $0.57(0.0665)^{* * *}$ & 0.93 & 7.47 & 0.18 \\
\hline Romania & $-9.65(0.0445)^{* *}$ & $0.55(0.0219)^{* *}$ & 1.10 & 6.41 & 0.26 \\
\hline Macedonia & $-9.70(0.0026)^{*}$ & $0.52(0.0011)^{*}$ & 0.69 & 4.25 & 0.47 \\
\hline Serbia & $-11.32(0.0242)^{* *}$ & $1.01(0.0167)^{* *}$ & -0.68 & 11.35 & 0.28 \\
\hline \hline
\end{tabular}

Notes: * - indicates significant at $1 \%$ level, ** - indicates significant at $5 \%$ level, and *** indicates significant at $10 \%$ level of significance.

Source: Authors’ own calculations. 
- The first column (1) gives the coefficients on the constant term, i.e. the estimated annual growth rate at the beginning of transition. Evidently, all the coefficients are negative, statistically significant constant coefficients, except for Albania and Croatia. The observation of the rates across countries shows that the lowest average annual growth rate (-11 and -12 percent, approximately) at the beginning of study period was recorded in Serbia and Bulgaria, respectively; followed by Macedonia and Romania (-9, approximately), suggesting that the drop was the most pronounced in these countries. For Croatia and Albania, these coefficients are insignificant, although the average shows a smaller initial drop.

- The second column (2) presents the estimated trend coefficients accompanied by their statistical significance. Evidently, all countries recorded a positive trend, i.e. positive increase in growth rates over the observed period, though the slopes are moderate varying from among 0.15 and 1.01 percent. All trend coefficients are significant. The highest trend coefficient is recorded in Serbia, while other Balkan countries record around 0.5 percent trend coefficient. These low trend coefficients are consistent with the lagging economic growth as compared to the Central Eastern European transition countries.

- Turning to the average growth rates shown in column (3) and the accompanying standard errors (column 4), it becomes obvious that only one country, Serbia, recorded a negative average annual growth rate (of -0.68 percent), which additionally is accompanied by the highest deviation from the trend (11.35 percent); followed by the group of countries with an average annual growth rate ranging from 0.69 to 0.93 (i.e. below 1 percent, Macedonia, Croatia and Bulgaria), accompanied by standard error ranging from 4.25 to 7.47. However, it should be noted that this estimation does not take into account possible breaks in the data series.

- Column (5) shows the R-squared of fitting a single time trend through growth rates $\left(y_{t}\right)$ or how much of the time series behaviour of GDP growth rates is just the trend. For most of the countries, the R-squared is very low. In fact, only two countries - Macedonia and Bulgaria - have an R-squared around 0.42 (means very low fit of the trend line), suggesting that for transition countries, growth is not just the trend.

In general, the results offered in Table 1 give a descriptive analysis but are inconclusive. The interpretations of the R-squared indicate a poor fit, suggesting that this basic regression trial has weak statistical relevance. This would suggest that growth was not just a trend in the course of transition. It has been marked by huge shifts in the growth rates that affected later rates of growth. 


\section{Conclusion}

The results support the hypothesis that the growth process in Balkan transition countries cannot be described simply by a single rising trend. Stylised facts of the macroeconomic data series of GDP recorded visible reversals and breaks due to big shocks happening in these economies for the whole period of transition; and the statistical significance of these shifts was confirmed by the simple linear regression analysis, which showed very poor statistical fit. In general, the assessment guides towards an in-depth study of the instability of growth by the use of a model that will give the possibility of replacing the familiar picture of long-run growth now and then impacted by business cycle fluctuations with a growth concept allowing for shifts or breaks in trend. Hence, in these cases, the analysis of economic growth must be matched with a non-linear modelling approach that will allow the parameters to adjust to reflect structural changes, but will be also informative on the dynamics around each particular trend line. As Durlauf et al. (2004) suggest many of the difficulties that face growth researchers could be addressed in ways that are now standard in the macro econometrics literature.

In general, this research puts forward the necessity for a novel line in growth process analysis, especially for the case of transition and developing economies, which experience structural shifts constantly, recording very high instability in economic growth. These breaks require inventiveness not only in the modelling approach that will allow the parameters to adjust to reflect structural changes; but also innovative method in the theoretical treatment of transition.

\section{References}

Abramovitz, M. \& David, P. (1973). Reinterpreting Economic Growth: Parables and Realities. The American Economic Review. Papers and Proceedings of the Eightyfifth Annual Meeting of the American Economic Association, May, 63(2), 428-439.

Aquiar, M. \& Gopinath, G. (2004). Emerging Markets Business Cycles: The Cycle is the Trend (NBER Working Paper, 10734), Cambridge, MA: National Bureau of Economic Research.

Balcerowicz, L. (2001). Post-Communist Transition: Some Lessons. Thirty - first Wincott Lecture. The Institute of Economic Affairs. 8 October 2001.

Ben-David, D. \& Papell, D. H. (1997). Slowdowns and Meltdowns: Growth Evidence from 74 Countries (NBER Working Paper, 6266), Cambridge, MA: National Bureau of Economic Research.

Berg, A., Borensztein, E., Sahay, R. \& Zettelmeyer, J. (1999). The evolution of output in transition economies: Explaining the differences (IMF Working Paper, WP/99/73), Washington, DC: IMF.

Blanchard, O. (1997). The Economic of Post-Communist Transition. Clarendon Lectures in Economics. Oxford: Oxford University Press.

Dabrowski, M., Gomulka S. \& Rostovski, J. (2000). Hence reform? A Critique of the Stiglitz Perspective. London: Centre for Economic Performance London School of 
Economics and Political Science, Retrived from: http://www.uh.edu/ vlazarev/4389/dabrowski.htm, Accessed on: 09.11.2017.

De Melo, M., Denizer, C. \& Gelb, A. (1996). From plan to market: Patterns of transition. World Bank Economic Review, 10(3), 397-424.

Durlauf, S. N., Johnson, P. A. \& Temple, J. R. W. (2004). Growth econometrics (Wisconsin Madison - Social Systems, Working Papers 18), Retrived from: http://irving.vassar.edu/faculty/pj/growtheconometrics.pdf, Accessed on: 09.11.2017.

Durlauf, S. N., Kourtellos, A. \& Tan, C. (2008). Are Any Growth Theories Robust? Economic Journal. Royal Economic Society. 118(527), 329-346.

Easterly. W., Kremer M., Pritchett L. \& Summers L. H. (1993). Good Policy or Good Luck? Country Growth Performance and Temporary Shocks (NBER Working paper, 4474), Cambridge, MA: National Bureau of Economic Research.

Easterly, W. (2009). The Anarchy of Success. Review of the books The Drunkard's Walk by L. Mlodinow and Bad Samaritans by H. Chang, The New York Review of Books, 56(15) (October 8, 2009) Retrived from: http://www.nyu.edu/fas/institute/dri/ Easterly/ File/NYR_sept09.pdf, Accessed on: 10.11.2017.

European Bank for Reconstruction and Development. (2009). Transition Report: Transition in crisis? EBRD, Retrived from: http://www.ebrd.com/downloads/ research/transition/TR09.pdf, Accessed on: 10.11.2017.

Hausmann, R., Pritchett, L. \& Rodrik, D. (2004). Growth Accelerations (NBER Working Paper, w10566), Cambridge, MA: National Bureau of Economic Research.

Jerzmanowski, M. (2006). Empirics on Hills, Plateaus, Mountains and Plains: A Markovswitching Approach to Growth. Journal of Development Economics, 81, 357-385.

Kornai, J. (2006). The Great Transformation of Central Eastern Europe. Economics of Transition, 14(2), 207-244.

NelsonC. R. \& Plosser C. I. (1982). Trends and random walks in macroeconomic time series: some evidence and implications. Journal of Monetary Economics, 10, 13962.

Perron, P. (1989). Testing for a Unit Root in a Time Series with a Changing Mean (Papers 347), Princeton: Department of Economics - Econometric Research Program.

Pritchett, L. (2000). Understanding Patterns of Growth: searching for hills among Plateaus, Mountains and Plains. The World Bank Economic Review, 14(2), 221-250.

Svejnar, J. (2002). Transition Economies: Performance and Challenges. Journal of Economic Perspectives, 16(1), 3-28.

World Bank. (2012). World Development Indicators. Washington, DC: World Bank.

\section{TESTIRANJE NESTABILNOSTI EKONOMSKOG RASTA U TRANZICIJI: SLUČAJ BAKANSKIH ZEMALJA}

Apstrakt: Stilizovane činjenice o rastu BDP-a zemalja u razvoju ili zemalja u tranziciji pokazuju da postoji velika razlika između njihovog rasta BDP-a i rasta BDP-a koji je karakterističan za razvijene zemlje. Naime, rast BDP-a zemalja u razvoju ili zemalja u tranziciji ima specifičnu karakteristiku nestabilnost rasta, koja je mnogo veća i različita od nestabilnost koja se javlja u razvijenim zemljama. Ovaj članak predstavlja napredak u proceni nestabilnosti 
rasta, promatrajući i testirajući taj koncept u slučaju nekoliko Balkanskih privreda. U toku tranzicije, Balkanske zemlje doživele su velike i iznenadne promene s pozitivnih na negativne prosečne stope rasta BDP-a (ili obrnuto) uzrokovane mnogim strukturnim, ekonomskim, političkim i društvenim promenama. Stoga, glavna svrha ovog rada je dati pregled najnovije literature o nestabilnosti rasta i empirijski analizirati koncept nestabilnosti rasta $u$ slučaju balkanske grupe zemalja u tranziciji, primenom jednostavne linearne regresione analize na seriji podataka o rastu BDP-a. Rezultati sugerišu da se proces rasta BDP-a u balkanskim privredama ne može opisati jednostavno jednim rastućim trendom budući da linearna regresiona analiza pokazuje vrlo slabu statističku vezu. Generalno, zaključci ukazuju na to da je potrebna dublja analiza nestabilnosti rasta $\mathrm{u}$ toku tranzicije i novi koncept rasta koji bi omogućio pomake ili prekide $\mathrm{u}$ trendu, praćen pristupom nelinearnog modeliranja koji će omogućiti da se parametri prilagode strukturnim promenama, karkterističnim za tranziciju.

Ključne reči: nestabilnost, ekonomski rast, privrede u tranziciji, Balkanske zemlje, serije podataka o BDP-u, linearna regresiona analiza.

\section{Author's biographies}

Nataša Trajkova-Najdovska is an Assistant Professor at the Faculty of Economics, University St. Kliment Ohridski in Bitola, where she teaches Principles of Economics, Entrepreneurship and Management of Small and Medium Enterprises. She has obtained her M. Sc. degree at the University St. Cyril and Methodius in Skopje and her PhD at Staffordshire University, Stokeon-Trent, United Kingdom. Her contemporary research interests encompass: theories of economic growth, transition economies, and institutions as factor for growth. She has published papers in scientific journals and has participated in national and international conferences in her home country and abroad. She is a researcher at the project supported by the CERGE -EI Teaching Fellowship Programme in Prague.

Snežana Radukić is an Associate Professor at the Faculty of Economics, University of Niš, where she teaches Microeconomics and Theory and Policy of Pricing. She has obtained her M. Sc. degree at the University of Belgrade, Faculty of Economics and her $\mathrm{PhD}$ at the University of Nišs, Faculty of Economics. Her contemporary research interests encompass microeconomics and sustainable development. She has published a book, three monographs, and numerous papers in scientific journals and proceedings of national and international conferences. She is a researcher at the project No. 44007 supported by the Ministry Education, Science and Technological Development of the Republic of Serbia. 